\title{
ISOLASI, SELEKSI DAN OPTIMASI BAKTERI PENGHASIL FITASE DARI TANAH VULKANIK DI GUCI, TEGAL
}

\author{
A. M. P. Nuhriawangsa ${ }^{1}$, A. Ratriyanto ${ }^{1}$, Sajidan $^{2}$ dan C. S. Purwati ${ }^{3}$ \\ ${ }^{\text {I} P r o g r a m ~ S t u d i ~ P e t e r n a k a n, ~ F a k u l t a s ~ P e r t a n i a n, ~ U n i v e r s i t a s ~ S e b e l a s ~ M a r e t, ~ S u r a k a r t a ~}$ \\ ${ }^{2}$ Program Studi Pendidikan Biologi, Fakultas Keguruan dan Ilmu Pendidikan, Universitas Sebelas \\ Maret, Surakarta \\ ${ }^{3}$ Jurusan Peternakan, Fakultas Pertanian, Universitas Veteran Bangun Nusantara, Sukoharjo \\ Email: adimagna@staff.uns.ac.id
}

\begin{abstract}
ABSTRAK
Tujuan dari penelitian ini adalah mengisolasi, menyeleksi dan mengkarakterisasi bakteri penghasil fitase yang diperoleh dari tanah vulkanik di Guci, Tegal. Bakteri dari tanah vulkanik diisolasi dan diseleksi pada media Luria Betany (LB) yang mengandung $4 \%$ asam fitat. Koloni terseleksi dioptimasi karakter fisiknya dengan melihat aktivitas relatif. Koloni bakteri dari tanah vulkanik dapat diisolasi, diseleksi dan mempunyai aktivitas relatif tertinggi pada TG3 dan TG3-5. Koloni bakteri TG3-5 penghasil fitat mempunyai nilai optimum tertinggi pada temperatur $55^{\circ} \mathrm{C}, \mathrm{pH} 7$, waktu inkubasi 90 menit, konsentrasi substrat 5\% dan kofaktor logam terbaik pada $\mathrm{Zn}^{2+}\left(10^{-4} \mathrm{M}\right)$. Tanah vulkanik di Guci, Tegal mengandung bakteri penghasil fitase dengan karakter fisik tertentu.
\end{abstract}

Kata kunci: Bakteri penghasil fitase, tanah vulkanik, karakter fisik, aktivitas relatif

\section{Isolation, Selection and Optimization of Phytase Producing-Bacteria from Vulcanic Soil in the Guci, Tegal}

\begin{abstract}
The purpose of this study was to isolated, selected and characterized phytase bacteria derived from volcanic soil in the Guci, Tegal. Bacteria from the volcanic soil was isolated and selected on Luria Betany (LB) media containing $4 \%$ phytic acid. Selected colonies were optimized by physical character with determining the relative activity. Colonies of bacteria could be isolated from the volcanic soil, selected, and had the highest relative activity in colonies of TG3 and TG3-5. TG3-5 bacterial colonies producing phytate had the highest optimum value at a temperature of $55^{\circ} \mathrm{C}, \mathrm{pH} 7$, the incubation time of 90 minutes, the substrate concentration of $5 \%$ and a best metal cofactor on $\mathrm{Zn}^{2+}$ $\left(10^{-4} \mathrm{M}\right)$. Volcanic soil in the Guci, Tegal containing phytase-producing bacteria with certain physical characteristics.
\end{abstract}

Keywords : Phytase-producing bacteria, volcanic soil, physical characteristics, the relative activity

\section{PENDAHULUAN}

Asam fitat merupakan inhibitor pakan karena mengikat mikronutrien dalam pakan secara kuat, sehingga mengurangi ketersediaan mikronutrien tersebut. Ternak monogastrik tidak dapat memanfaatkan fitat karena tidak tersedia fitase dalam salauran pencernaannya (Gupta et al., 2015). Fitase dapat menghidrolisis asam fitat sehingga dapat meningkatkan retensi mineral dalam bahan pakan (Liu et al., 2015). Fitase berpengaruh secara positif terhadap performan, profil darah (Nuhriawangsa et al., 2011) dan kualitas pakan pada ayam broiler (Nuhriawangsa et al., 2012). Selain 
itu fitase juga dapat meningkatkan kecernaan serin, asam aspartat, $\mathrm{Ca}$ dan $\mathrm{P}$, sehingga dapat menguntungkan jika digunakan dalam pakan ayam broiler (Manobhavan, et al., 2016).

Pada pembuatan pakan ternak memerlukan suhu yang tinggi, maka memerlukan fitase yang stabil pada suhu tersebut (Kanpiengjai, 2013). Dengan demikian maka mikroorganisme termofilik menjadi penting untuk menghasilkan enzim yang stabil terhadap panas untuk produk komersial (Mehta et al., 2016).

Isolat dari area tanah vulkanik di Selo, Jawa Tengah dan Cangkringan, Yogyakarta, Indonesia mampu menghasilkan fitase ekstraseluler yang mampu mendegradasi asam fitat (Sajidan et al., 2015). Bakteri penghasil fitase dapat diisolasi dan dikarakterisasi dari sumber air panas dari Guci, Tegal (Purwati et al., 2016).

Pada pembuatan pakan ternak diperlukan fitase yang stabil terhadap panas. Hal ini disebabkan karena saat pembuatan pakan ternak menggunakan temperatur dengan kisaran $60-90^{\circ} \mathrm{C}$. Indonesia merupakan daerah tropis dengan beberapa gunung vulkanik, sehingga kaya akan plasma nutfah bakteri penghasil fitase. Dengan demikian diharapkan penelitian ini dapat mengisolasi, menyeleksi dan mengkarakterisasi bakteri penghasil fitase yang diambil dari tanah vulkanik di daerah Guci, Tegal yang bisa menghasilkan fitase termostabil untuk produksi pakan komersial.

\section{MATERI DAN METODE}

Penelitian ini menggunakan materi tanah vulkanik di Guci, media LB cair yang diperoleh dengan mencampurkan tripton
$10 \mathrm{~g}$, ekstrak yeast $5 \mathrm{~g}$ dan $\mathrm{NaCl} 10 \mathrm{~g}$ pada per liter aquabides, LB padat dengan mencampurkan $15 \mathrm{~g}$ agar dalam 1 liter LB cair, Na-fitat, Na-asetat, kofaktor berbagai ion $^{2+}$ dan aquades.

Satu gram tanah vulkanik dilarutkan dalam $1,5 \mathrm{ml} \mathrm{NaCl}$ fisiologis untuk mengisolasi isolat bakteri penghasil fitase dengan cara streak pada LB padat yang diinkubasi selama 18 jam pada suhu $37^{\circ} \mathrm{C}$. Isolat dengan aktivitas relatif tertinggi merupakan isolat hasil seleksi yang digunakan untuk optimasi karakteristik fisik. Penghitungan aktifitas relatif dengan cara melihat absorbansi terkoreksi sampel $\mathrm{x}$ 100\%. Adapun absorbansi terkoreksi dihitung dengan cara absorbansi sampel dikurangi kontrol dibagi dengan absorbansi sampel tertinggi dikurangi kontrol. Absorbansi dilihat dengan spektrofotometer pada panjang gelombang $400 \mathrm{~nm}$ pada media LB cair dengan isolat bakteri penghasil fitase yang telah diinkubasi dibanding kontrol (Sajidan, 2002).

Optimasi koloni bakteri dilakukan untuk mengetahui karakter fisik (temperatur, $\mathrm{pH}$, waktu inkubasi, konsentrasi substrat dan kofaktor logam) pada berbagai konsentrasi. Hasil optimasi diperoleh dengan melihat jumlah pertumbuhan mikrobia berdasarkan nilai absorbansi pada spektrofotometer dengan melihat aktifitas relatifnya (Sajidan, 2002).

\section{HASIL DAN PEMBAHASAN}

Bakteri penghasil fitase berupa koloni telah dapat diisolasi dari tanah vulkanik di Guci, Tegal tampak pada Gambar 1.
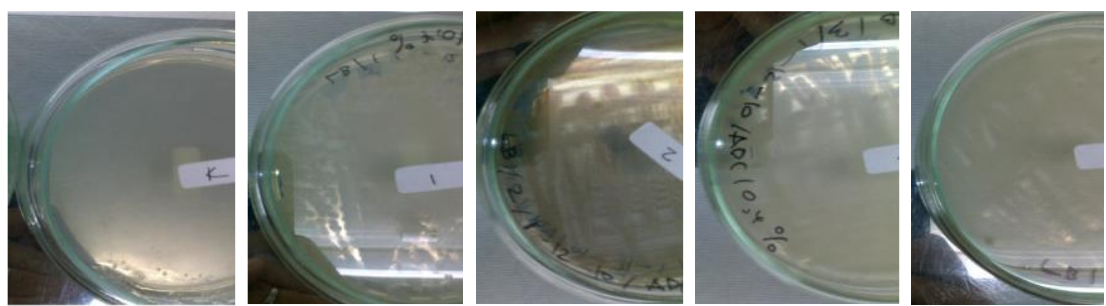

Gambar 1. Koloni bakteri penghasil fitase dalam media LB padat dengan asam fitat $0,2 \%(\mathrm{~K}=$ kontrol, TG1-4 = koloni bakteri 1 sampai 4$)$ 

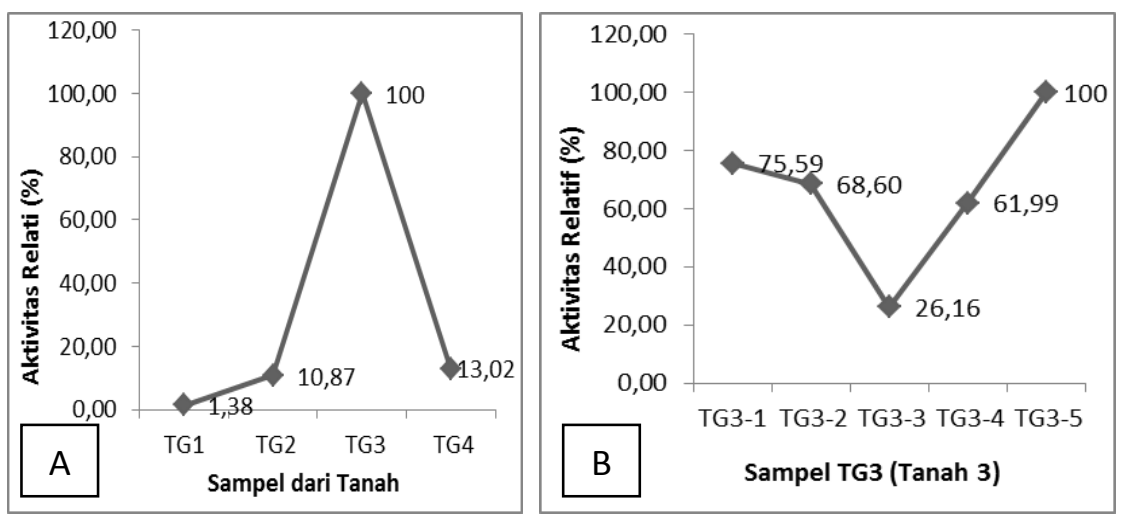

Gambar 2. Seleksi aktivitas relatif bakteri yang diambil dari tanah vulkanik Guci koloni TG1 sampai 4 (A) dan TG3-1 sampai 5 (B)

Koloni bakteri penghasil fitase berhasil diisolasi dan hal ini sesuai dengan beberapa penelitian lain. Beberapa bakteri penghasil fitase dapat diisolasi dari akar rizofer tanaman yang tumbuh pada tanah vulkanik di Chili (Jorquera et al., 2008; Jorquera et al., 2011). Bakteri penghasil fitase dapat disiolasi dari tanah pegunungan Himalaya, Uttarakhand, India Utara (Kumar et al., 2013). Bakteri penghasil fitase dapat diisolasi dari abu vulkanik di daerah Selo, Jawa Tengah dan Cangkringan, Boyolali (Sajidan et al., 2015).

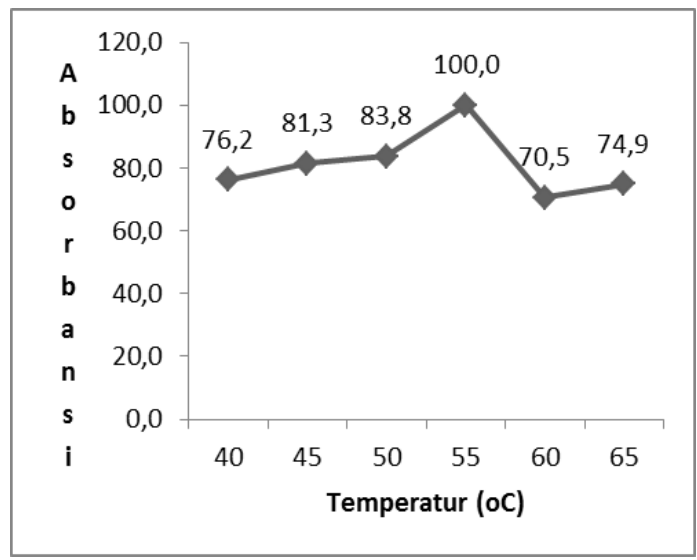

Gambar 3. Optimasi temperatur koloni bakteri TG3-5 (Absorbansi = aktivitas relatif)

Koloni bakteri TG3 dan TG3-5 menunjukkan adanya aktivitas relatif yang tertinggi. Penelitian Sajidan et al. (2015) menunjukkan bahwa bakteri yang diisolasi dari tanah di daerah vaulkanik Jawa Tengah mempunyai aktivitas mendegradasi asam fitat. Begitu pula bakteri yang diisolasi dari akar rizofer tanaman yang tumbuh pada tanah vulkanik di Chili (Jorquera et al., 2008; Jorquera et al., 2011). Bakteri Bacilllus cereus, Bacillus aryabhattai dan Bacillus cereus hasil isolasi dari sumber abu vulkanik Merapi menghasilkan fitase dengan aktivitas tertentu (Wulandari et al., 2011).

Bakteri koloni TG3-5 mempunyai temperatur optimum pada $55^{\circ} \mathrm{C}$ (Gambar 3 ). Beberapa penelitian mempunyai hasil yang berbeda dengan penelitian ini. Secara berurutan isolat bakteri D10, MC6, MS5, D16, D6 dan MC8 yang diisolasi dari tanah vulkanik di Jawa Tengah mempunyai aktivitas optimum fitase ekstraseluler pada temperatur 50, 60, 60, 50, 60 dan $40^{\circ} \mathrm{C}$ (Sajidan et al., 2015).

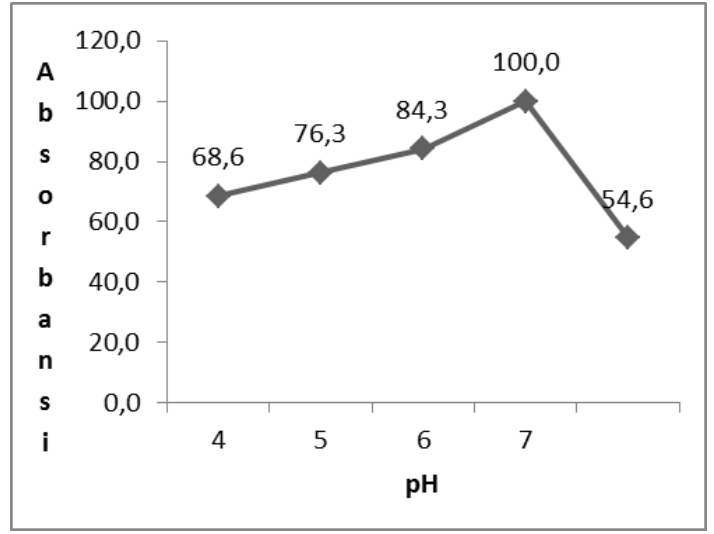

Gambar 4. Optimasi pH koloni bakteri TG35 (Absorbansi $=$ aktivitas relatif)

Bakteri koloni TG3-5 mempunyai pH optimum pada nilai 7,0 (Gambar 4). 
Beberapa penelitian mempunyai hasil sama dan berbeda. Fitase yang terkait pada sel bakteri Bacillus sp. MQH-19 dan Paenibacillus sp. SPT-03 mempunyai pH optimum 7,0 dan 4,5 (Acuna et al., 2011). Isolat bakteri D10, MC6, MS5, D16, D6 dan MC8 dari tanah vulkanik di Jawa Tengah mempunyai aktivitas optimum fitase ekstraseluler pada $\mathrm{pH} 4,0,5,0,6,0,6,0,6,0$ dan 6,0 (Sajidan et al., 2015).

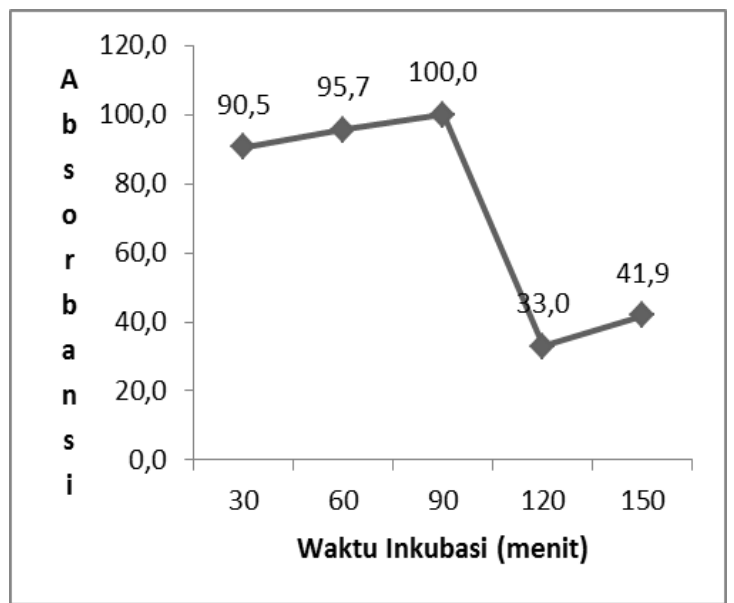

Gambar 5. Optimasi waktu inkubasi koloni bakteri TG3-5 (Absorbansi = aktivitas relatif)

Bakteri koloni TG3-5 mempunyai waktu inkubasi optimum 90 menit (Gambar 5). Peneliti yang lain mempunyai hasil yang berbeda. Isolat bakteri dari tanah vulkanik di Jawa Tengah aktivitas ekstrak kasar fitase menggunakan waktu inkubasi 60 menit (Sajidan et al., 2015). Bakteri yang berhasil diisolasi dari tanah vulkanik di Chili, aktivitas fitasenya diukur dengan menggunakan waktu inkubasi 30 menit (Acuna et al., 2011).

Bakteri koloni TG3-5 mempunyai konsentrasi substrat optimum 5\% (Gambar 6). Beberapa penelitian menunjukkan hasil yang berbeda. Aktivitas ekstrak kasar fitase menggunakan konsentrasi substrat $5 \mathrm{mM}$ sodium fitat untuk isolat bakteri dari tanah vulkanik di Jawa Tengah (Sajidan et al., 2015). Bakteri yang berhasil diisolasi dari tanah vulkanik di Chili, aktivitas fitasenya diukur dengan menggunakan konsentrasi $270 \mu \mathrm{l} \mathrm{Na-fitat} \mathrm{cair} \mathrm{(Acuna} \mathrm{et} \mathrm{al.,} \mathrm{2011).}$

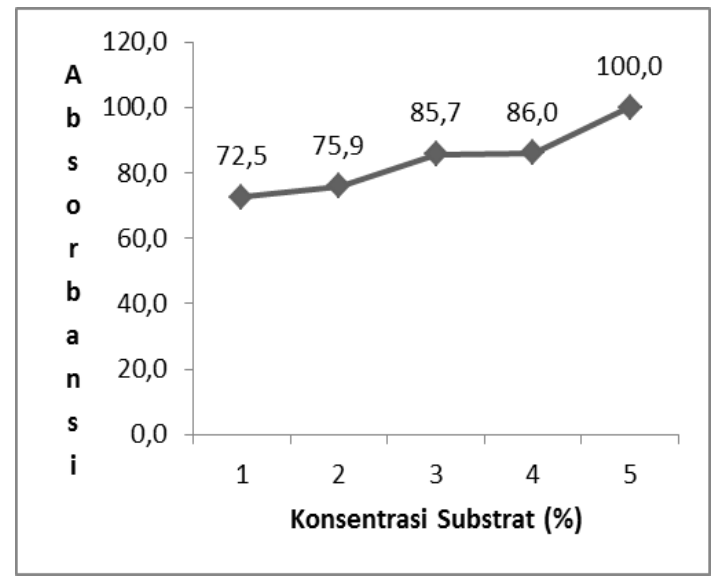

Gambar 6. Optimasi konsentrasi substrat koloni bakteri TG3-5

(Absorbansi $=$ aktivitas relatif $)$

Bakteri koloni TG3-5 mempunyai kofaktor ion optimum pada $\mathrm{Zn}^{2+}$ (Gambar 7). Beberapa penelitian menujukkan perbedaan. $\mathrm{Zn}^{2+}$ dan $\mathrm{Fe}^{3+}$ bersifat inhibitor terhadap semua ekstrak kasar fitase sel bakteri yang diisolasi dari tanah vulkanik di Jawa Tengah (Sajidan et al., 2015). $\mathrm{Mn}^{2+}$ bersifat kofaktor pada bakteri yang berhasil diisolasi dari tanah vulkanik di Chili (Acuna et al., 2011).

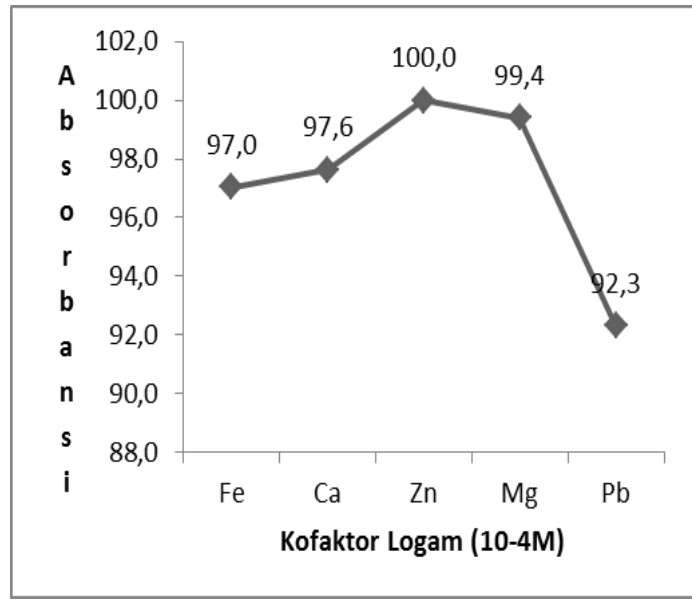

Gambar 7. Optimasi kofaktor logam koloni bakteri TG3-5

(Absorbansi $=$ aktivitas relatif $)$

\section{KESIMPULAN}

Bakteri penghasil fitase dapat diisolasi dari tanah vulkanik di Guci, Tegal dan mempunyai karakter fisik tertentu (temperatur $55^{\circ} \mathrm{C}, \mathrm{pH} 7$, waktu inkubasi 90 
menit, konsentrasi substrat 5\% dan kofaktor $\operatorname{logam} \mathrm{Zn}^{2+}$ dengan konsentrasi $10^{-4} \mathrm{M}$ ).

\section{DAFTAR PUSTAKA}

Acuna, J. J., M. A. Jorquera, O. A. Martínez, D. Menezes-Blackburn, M. T. Fernandez, P. Marschner, R. Greiner and M. L. Mora1. 2011. Indole acetic acid and phytase activity produced by rhizosphere bacilli as affected by $\mathrm{pH}$ and metals. Journal of Soil Science and Plant Nutrition. 11(3):112.

Gupta, R. K., S. S. Gangoliya, and N. K. Singh. 2015. Reduction of phytic acid and enhancement of bioavailable micronutrients in food grains. Journal of food science and technology. 52(2): 676-684.

Jorquera, M. A., M. T. Hernández, Z. Rengel, P. Marschner and M. de la L. Mora. 2008. Isolation of culturable phosphobacteria with both phytatemineralization and phosphatesolubilization activity from the rhizosphere of plants grown in a volcanic soil. Biology and Fertility of Soils. 44:1025-1034.

Jorquera, M. A., D. E. Crowley, P. Marschner, R. Greiner, M. T. Fernandez, D. Romero, D. M. Blackburn and M. de la L. Mora. 2011. Identiфcation of b-propeller phytase-encoding genes in culturable Paenibacillus andBacillus spp. fromthe rhizosphere of pasture plants onvolcanic soils. Federation of European Microbiological Societies Microbiology Ecology. 75(2011):163-172.

Kanpiengjai, A., K. Unban, R. Prathanaphon and C. Khanongnuch. 2013. Optimal medium and conditions for phytase production by thermophilic bacterium, Anoxybacillus sp. MHW14. Food and Applied Bioscience Journal. 1(3): 172-189.
Kumar, V., P. Singh, M. A. Jorquera, P. Sangwan, P. Kumar, A. K. Verma and S. Agrawal. 2013. Isolation of phytase-producing bacteria from Himalayan soils and their effect on growth and phosphorus uptake of Indian mustard (Brassica juncea). World Journal Microbiology and Biotechnology. 29(2013):13611369.

Liu, S. Y., R. M. Boldb, P. W. Plumsteadb, P. H. Selle. 2015. Effects of 500 and 1000FTU/kg phytase supplementation of maize-based diets with two tiers of nutrient specifications on performance of broiler chickens. Animal Feed Science and Technology. 207(2015):159-167.

Manobhavan, M., A. V. Elangovan, M. Sridhar, D. Shet, S. Ajith, D. T. Pal and N. K. S. Gowda. 2016. Effect of super dosing of phytase on growth performance, ileal digestibility and bone characteristics in broilers fed corn-soya-based diets. Journal of Animal Physiology and Animal Nutrition. 100(1): 93-100.

Mehta, R., P. Singhal, H. Singh, D. Damle and A. K. Sharma. 2016. Insight into thermophiles and their widespectrum applications. Biotechnology. 6:81(1-9).

Nuhriawangsa, A. M. P., Z. Bachruddin, Sajidan, and A. Wibowo, 2011. Pengaruh Pemberian Fitase dari Bakteri Rekombinan pEAS1-AMP Asli Indonesia terhadap Performan Produksi dan Profil Darah pada Ayam Broiler Fase Grower. In: Proceeding of National Seminar on Zootechniques for Indogenous Resources Development. Faculty of Animal Agriculture Diponegoro University, JPPT and Indonesian Society of Animal Agriculture, Semarang. ISAA Publication. 1(2012): 203-208.

Nuhriawangsa, A. M. P., Z. Bachruddin, Sajidan, and A. Wibowo, 2012. 
Aplikasi Fitase dari Bakteri Rekombinan pEAS1-AMP untuk Meningkatkan Kualitas Pakan dan Kinerja Produksi Ayam Broiler yang Ramah Lingkungan. Dalam: Prosiding Seminar Nasional Peternakan Berkelanjutan 4: Inovasi Agribisnis Peternakan untuk Ketahanan Pangan: Komoditas Unggas. Fakultas Peternakan UNPAD, Bandung. Hal: 220-225.

Purwati, C. S., Sajidan, A. Ratriyanto dan A. M. P. Nuhriawangsa. 2016. Seleksi dan optimasi karakter fisik bakteri penghasil fitase yang diisolasi dari sumber air panas di Guci, Tegal. Sains Peternakan. 13(2): 1-6.

Sajidan, R. Wulandari, E. N. Sari, A. Ratriyanto, H. Weldekiros and R. Greiner. 2015. Phytase-producing bacteria from extreme regions in Indonesia. Brazilian Archives of Biology And Technology. 58(5): 711717.

Wulandari, R., Sajidan dan Suranto. 2011. Analisis Gen 16s rRNA pada Bakteri Penghasil Enzim Fitase. Naskah Publikasi Thesis. Program Studi Magister Biosains, Program Pasca Sarjana, Universitas Sebelas Maret, Surakarta. 